Mercator, Fortaleza, v. 17, e17027, 2018.

DOI: https://doi.org/10.4215/rm2018.e17027

ISSN: $1984-2201$

Copyright @ 2002, Universidade Federal do Ceará

\title{
CITIES IN THE AMAZON, TERRITORIAL SYSTEMS AND THE URBAN NETWORK
}

BARTOLI, Estevan; ${ }^{\text {* }}$

(a) PhD in Geography. Professor State University Amazonas (UEA), Parintins (AM), Brazil. ORCID ID: https://orcid.org/0000-0003-1238-3187. CURRICULUM LATTES: http://lattes.cnpq.br/0618624782475219

\section{(*) CORRESPONDING AUTHOR}

Address: Estrada Odovaldo novo, s/n. CEP: 69152-470 - Parintins (AM), Brazil. Tel: (+55 62) 991305120.

E-mail: estevangeo@hotmail.com

Starting from theoretical premises on urban networks in the Amazon that highlight the incomplete character of the cities' economies and their unconsolidated hinterlands, this proposal discusses the Urban Riparian Territory System (STUR), which is dynamized through navigation and belongs to the grassroots economy. Data from Parintins (AM), evidences the distribution of industrialized goods to surrounding areas and supply of the urban market with regional resources. The STUR also affects the structuring of intraurban space forming low-income neighborhoods, shaping riverfronts that function as multireticular nodes. There is a complex interaction with the dominant territorial system linked to commercial capital, showing the dual and complementary character of this grassroots economy.

Keywords: Territorial system, City, Grassroots economy, Navigation.

\section{RESUMO / RESUMEN}

\section{CIDADES NA AMAZÔNIA, SISTEMAS TERRITORIAIS E A REDE URBANA}

Partindo de premissas teóricas sobre redes urbanas na Amazônia que destacam o caráter incompleto das economias das cidades e suas hinterlândias não consolidadas, propomos discussão sobre o Sistema Territorial Urbano-Ribeirinho (STUR): sistema pertencente à economia popular dinamizado pela navegação. A partir de dados relativos a Parintins (AM) constata-se distribuição de bens industrializados para áreas circunvizinhas e abastecimento do mercado urbano com recursos regionais. O STUR afeta ainda a estruturação do espaço intraurbano pela formação de bairros populares, configurando beiras de rio que funcionam como nós multireticulares. Observa-se complexa interação com o sistema territorial dominante atrelado ao capital mercantil, conferindo caráter dual e complementar dessa economia popular.

Palavras chaves: Sistema territorial, Cidade, Economia popular, Navegação.

\section{CIUDADES EN LA AMAZONIA, SISTEMAS TERRITORIALES Y LA RED URBANA}

La propuesta es una discusión sobre el Sistema Territorial Urbano Ribereño (STUR), un sistema dinamizado por la navegación y perteneciente a la economía popular, desde premisas teóricas sobre redes urbanas en la Amazonía que resaltan el carácter incompleto de las economías de las ciudades y las zonas del interior no consolidadas. Utilizando datos de Parintins (AM) podemos ver la distribución de bienes industrializados a las áreas circundantes y el suministro del mercado urbano con recursos regionales. El STUR también afecta la estructuración del espacio intraurbano por la formación de barrios populares, configurando la orilla del río que funcionan como nodos multireticulares. Esta economía popular muestra una compleja interacción con el sistema territorial dominante vinculado al capital mercantil, confiriendo un carácter dual y complementario.

Palabras-clave: Sistema territorial, Ciudad, Economía popular, Navegación. 


\section{INTRODUCTION}

Theoretical assumptions that question the capacity of cities in the Amazon to order their surrounding territories, point out that most urban economies do not have consolidated hinterlands (BECKER, 2013), thus presenting poorly diversified economies and low dynamism. Within this context, faced with the accelerated process of urbanization and exodus, diverse populations have reconstructed spatial practices associated with new conditioning factors from the city, with an intensification of the sub-regional circulation (inland navigation), alterations in intra-urban space and the resumption or maintenance of territorial links. This is dealt with in the first part of the text.

The second part returns to analytical proposals on thematic networks which aid the understanding of these dynamics, considering the fixed assets and flows that structure the territorial system. This is the sector of the urban grassroots economy that needs to carry out constant displacements to maintain economic activities.

The present text is part of wider research developed in Bartoli (2017), using the territorial approach that can make good contributions towards thinking about the relational and procedural character in studies of cities in the Amazon. The system of multidimensional analysis present in the territorial approach (RAFFESTIN, 1993; DEMATTEIS, 2005; 2008; SAQUET, 2007; 2011), covers economics, politics, culture and nature (EPCN). In this sense, the struggles for systems of appropriation, valuation and representation are evidenced, loaded with the intentionality of the subjects who compete over assets for territorial planning. Such a method is seldom used when posing this problem, mainly questioning the role they play in facilitating actions of networks of varied subjects.

With the application of semi-directed questionnaires, we aim to describe aspects that make up the structure of the urban systems in question, which can be subdivided into two strands. The first is related to the activities that have aspects linked to the grassroots economy found in the cities: adaptations of techniques, informality, spatial practices to acquire regional resources and forms of propagation of uncoded knowledge that are associated with "modern" aspects of the urban economy. This traditional knowledge, associated with the "city environment", includes: 1) ways of moving around the territory; 2) connecting the urban node to several points; and 3) extracting and processing regional products, complementing the city's economy.

The second strand resides in the ability of networks of subjects to "use" the city to construct collective projects (with a certain territorial identity). Modern techniques are adapted to traditional ones. They build environments in low-income neighborhoods (riverbanks, grassroot markets, on stilts and floating) that, although fragile and with little propensity to move towards a relative autonomy, produce their own territories of influence through territorialities. Such systems are responsible for the formation of new "capillarities" from the urban sphere, the basis of action and a milieu of different networks of subjects with different degrees of organization.

The data collection related to Parintins interviewed 114 owners of medium-sized regional vessels belonging to the grassroots economy. It was evidenced that the local network of the survey's subjects, from riverbanks in low-income neighborhoods and the central area (multireticular nodes), is redesigning displacement strategies to neighboring communities and municipalities, distributing industrialized goods and at the same time bringing regional natural resources back to the city, such as cattle and agricultural produce, complementing the grassroots circuits of the urban economy (informal trade, markets, small butcher shops, etc.). They also supply sectors of the dominant commercial capital in the city (lumber yards, meatpackers, slaughterhouses, etc.).

In the third part of the text, what we call the Territorial Urban-Riparian System (STUR), relates to the methodological proposal to understand the dynamics of such local networks of subjects belonging to the grassroots economy, who through inland navigation small or medium-sized boats for private and / or family use), interconnect and overlap the "urban with the riverside", complementing the local economy. 
It is necessary to list elements for the renewal of an interpretation of territories from the city, since populations previously distanced from the "presence" of the city (access to services, education, institutions, consumer goods, etc.) such as indigenous people and population in the interior, have come to enjoy urban interaction as a facilitator of new connections with rural environments and surrounding communities and villages.

\section{CITIES AND TERRITORIES}

Some of the academic interpretations of cities in the Amazon region deal with aspects of dynamics that interfere in the production of regional space, such as the roles of mediation, polarization, centrality, political and cultural influence or territorial responsibility, ${ }^{1}$ thus characterizing the representative functions of cities (in a general sense).

Within the logistical role, Amazonian cities connect diverse transportation modes, functioning as centers of supply and distribution of services and goods to surrounding areas (including Indigenous Lands, Conservation Units and smaller cities). They have millions of consumers, host the headquarters of public and private institutions, facilitating access to health and education services, offer employment and income alternatives, hold back migration to the forest, or serve as potential centers of agrarian reform settlements (BECKER, 2004).

Since the 1970s, several realities linked to regional and urban spatial production have been forming in the Amazon, giving rise to a mosaic of cities linked to the most varied expansion fronts of capitalist activities, resulting in what Trindade Jr. (2010) called urbanodiversity.

In the development of this urban network, these expansion fronts of cities' development were consolidated through "their relationships originating from older urban structures and subject to recent transformations" (VICENTINI, 2004, p.62). In this context, studies of typologies emerge to characterize the change in the pattern of organization of regional space and greater complexity in contents and forms, either by the historical role activated and later deactivated by the emergence of new fronts, or in modern cities originating from large projects (mining, for example). Theoretical efforts to understand expansion fronts, urbanization directed by private colonization (colonizing companies), official state colonization (BECKER, 1990; VICENTINI, 2004), riparian cities (TRINDADE JUNIOR - 2010), or the role of medium-sized cities (OLIVEIRA \& SCHOR, 2010; SCHOR et al. 2009) are some examples of the manifestation of the urban process in the region.

Such approaches leave explanatory gaps about the multidimensional and trans-scalar mediations performed by networks of local subjects influencing the surrounding areas, whose interpretation in the present text occurs from the analysis of territorial systems. In general, Amazonian cities have been linked in their evolutionary paths to forms of domination, geographic and social concentration of a surplus of production and population displacement, with urbanization being a strategy of capital to occupy and control the frontier quickly (GENTIL, 1988, p.74). In successive cycles of product valorization, there is a growing influence of cities mediating territorial dynamics: sectors of the urban economy organize territorial systems that configure fixed assets and flows, detailed below, indicating the ability of networks of subjects to project themselves on the territory.

This urbanization of the regional frontier has a particular characteristic because it is "disjointed from its own development and goes beyond the internal limits of growth that the speed of development of the region can impose" (BROWDER, GODFREY, 2006, p 102). In the process of urbanization geographic space has an essential nerve of intermediation of the relationships of domination, as Santos and Silveira (2003) point out, where more profitable products receive primacy over others, inserting a spatial specialization, causing the devaluation of certain activities in favor of others. This geographical specialization of production is responsible for a massification of capital,

(1) Schor and Oliveira (2016) emphasize the presence of health services in Parintins, which increases its territorial responsibility, as the city starts to attend surrounding municipalities. 
which "imposes a wider spatial scale on the market, and one can speak of both a regional alienation and an alienation of man-producer" (Ibid, 145), causing collapse in local cities.

For Becker (2013), the explanation of the non-development of the cities in the Amazon lies in the absence of new divisions of work capable of changing the condition of growth of the economy. Such divisions would stimulate trade and encourage the substitution of imports, allowing the organization of the urban network and creating mutual relationships between cities, thus breaking down the hierarchical routes that dominate urban nuclei where this failure, existing until the present in the absence of added value to exported products, "is one of the main reasons for the insufficiency of urban dynamism. The small manufactures created soon succumbed with the decline of the surge (Becker, 2013 - page 19).

According to Becker (2013, p.44-45), most of the cities, having experienced only a surge of economic growth, did not alter their content, structure and complexity, remaining in the condition of central places, without an organized hinterland. He also points out that, unlike the theory of central places, these cities' process of consolidation does not lead to the spatial regularity of the influence of these flows, where the natural conditions of cities in the Amazon probably create locations with dispersed nuclei, while social differentiations to can create regional patterns of city clusters.

In this context, several cities have developed territorial systems based on fractions of commercial capital associated with sectors of the grassroots economy, using cities as multireticular nodes for extraction (with rare processing) of regional resources. At the same time, they are distributors of various industrialized products to inland areas, some of which are essential for the functioning of the territorial system, as in the case of the trade in food and fuel. There are several examples in the State of Amazonas: the extraction of piassava (ARAÚJO, 2016) and ornamental fish in the channel of the Rio Negro (Barcelos), the extensive commercialization network of fish in the cities of the upper Solimões (MORAES, 2012), the management of Pirarucu in Tefé and Fonte Boa, the guarana of Maués or illegal gold prospecting on rafts on the Madeira river in the municipality of Novo Aripuanã, among many others.

Such territorial systems with ordering nodes in the cities are dynamized by networks of subjects belonging to the grassroots economy, whose articulations with dominant systems of local markets configure spatial arrangements that allow the maintenance of activities. Gold prospecting, logging, and meat packers have strong support from mayors, establishing themselves as dominant sectors in the city, attracting migratory flows and modeling the landscape through fixed assets. Among them, low-income neighborhoods and their complex riversides, which establish multireticular nodes connecting them to the interiors, and thus still allowing trans-scalar relationships, where most products are exported without processing, constituting incomplete productive chains.

In this sense, it is necessary to describe the characteristics of the grassroots economy that articulate new technical, cultural and political mediations (also considering the cohesion of networks of subjects in organized collectives such as cooperatives, associations and fishermen's colonies). Therefore, there are interpretative gaps regarding the existing territorial links from the consolidation of the territorial systems originating in the grassroots economy, affected by the accelerated process of urban growth and rural exodus. Such links are altered, broken, and in many cases reassembled by the way subjects articulate themselves in the city and "return to territories".2

Exploring the nature of the internal and trans-scalar relationships of the riparian cities or medium-sized cities with intense riparian dynamics (as in the case of Parintins), directs us to the understanding of the relational meaning of regional spatial practices that demonstrate specific permanences and temporalities (TRINDADE JR et al. 2008) .

(2) In Bartoli (2017) we demonstrate the multidimensionality present in returns to territories of urban groups like indigenous people, fishermen, those engaged in extractivism and producers of regional vessels. These "returns" were differentiated by the way the groups formulated projects in organized collectives, changing the way they articulated territories from the city: new techniques, differentiated markets reached, scalar leaps or greater submission to the regional urban market. 
Recent transformations in riparian cities point precisely to the redefinition of contents and processes (TRINDADE Jr., et al., 2008; SILVA and MALHEIRO, 2005). For Trindade Jr. et al. (2008, p.38), riparian cities have a strong socio-economic and cultural influence with a local and regional geographic scale and are rooted in ways of life and interactions established between city dwellers and fluvial courses. They also emphasize the importance of an interpretation that goes beyond absolute location, where this interaction takes on a functional character (inland navigation and use for domestic activities), material subsistence (source of food and economic resources), a ludic and cultural symbol (Ibid., pp. 42).

For Oliveira (2000), the process of urbanization in the Amazon is not necessarily due to the presence of cities in the regional landscape (urbanization of the territory), but mainly by the diffusion of urban society, which also expands urban influence. The generalization of the urban phenomenon in the Amazon is discussed from the identification of contradictory processes, based on a tripod: the destruction of existing spatial forms, the creation of resistances and the reconstruction of spatial forms and contents endowed with new dimensions and meanings. The author considers that the socio-spatial practice, the geographic location of social action, reveals alternatives of liberation of relationships in the city.

Faced with these setbacks, the spatial behavior from commercial and grassroots territorial systems of these cities (riparian or medium-sized cities with strong riparian dynamics), appears as a central problem. There are few dynamic cities favored by the commerce associated with their position and situation (a favorable characteristic in the case of Parintins). The formation of "incomplete" urban economies, incapable of sustaining populations through eminently urban activities, ends up provoking reformulations of a large part of the territorial links to complement the urban economy.

The different modalities of return to the interior areas for income complementation and the maintenance of diverse activities by the working class are more intense than has been imagined. Vernacular practices are adapted to new territorialities, projects and actions through the influence that the urban environment exerts: navigation, extractivism, fishing, etc., gain new "contours" (the territory of influence of the city expands) when submitted to the urban market and the availability of techniques, information and incentives provided in the interactive environment of the city.

Indigenous and internal populations previously distant from the presence of the city as a resource, from access to consumer goods, education, institutions, etc., now enjoy the urban environment that enables new interactions with rural environments, communities and villages. There is also the possibility of scalar jumps through the support from various institutions (NGOs, universities, fair trade networks, the solidarity economy, government programs, etc.) using the city as a logistical base (BARTOLI, 2015, 2017).

In the face of the "incomplete" urban economy of most agglomerations, guiding questions were defined, related to aspects of the spatial behavior of the grassroots economy from the data obtained on Parintins. How are the spatial practices of the grassroots sectors reestablished from the city? How does the conformation of the grassroots economy circuit through navigation, also fulfill the role of distribution of industrialized consumer goods? Finally, what are the main elements that structure the STUR in its sub-regional dynamics and what are the spatial repercussions in the intra-urban space?

\section{EXTENSIVE URBANIZATION, THEMATIC URBAN NETWORKS AND TERRITORIAL SYSTEMS}

Before considering the data obtained on Parintins, we will make brief considerations about the theoretical contributions of urban networks' dynamics in the Amazon that help support the STUR model. We started with approaches related to the regional and subregional scale, where the lack of economic dynamism of the cities is complemented by the commercialization of industrialized 
consumer goods (extensive urbanization); then we returned to studies of urban networks linked to the extraction and commercialization flows of regional resources: wood, fish, guaraná, etc. (thematic networks), where the local scale is considered, whose fixed assets in the intraurban-riparian space provide the structure of such networks.

With the acceleration of regional settlement after the military period, the formation of new means of communication and transportation that connect cities in different forms of access to the networks occurred in the Amazon region, as Monte-Mór (2009) emphasizes, for "beyond rivers" , there are new urban centralities, extrapolating the limits of the cities and expressing a broad economic-spatial process that the author calls extensive urbanization (MONTE-MÓR, 1994). This urbanization surpasses city barriers, penetrating all the regional spaces, favored by the development of the technical-scientific and informational environment and by the support of the strong presence of the relationships of urban-industrial production. For the author, city-rural relationships would enter into this logic, since:

This dialectical synthesis that overcomes the city-rural relationship within a collective and political logic, centered in the struggle for daily life and privileging the aspects of social reproduction, presenting densities, sizes and forms of varied socio-spatial organization, but all of it within an urban-industrial logic composed of equivalent general conditions of production and an industrial-based collective consumption, which I have called extensive urbanization (Monte Mor, 2004, 24).

Monte-Mór (2009), also points to the fragility of Amazonian urban networks due to the existence of a series of impediments such as: the great distances between the capital and other cities, the lack of infrastructure (transportation and communication), and the large proportion of the population deprived of material and educational resources that are decisive for their active participation in the various types of flows. For the author, flows cannot be realized if there is not a communications network adequate to their characteristics and thus an obstruction to the faster propagation of exogenous innovations.

Therefore, to understand the Amazonian networks, it is necessary to identify which flows interconnect cities. In this context, meeting the demand for food in the urban market has been changing a growing number of items of the regional diet, with a marked presence of canned food, frozen chicken, cured meats and other industrialized products (MORAES \& SCHOR, 2010; MORAES, 2008; ). Other industrialized foods are junk food ${ }^{3}$ such as Nestlé products; the company offers incentives so that they reach the most distant corners of underdeveloped countries. In the Amazon, the company has used large distribution vessels that were gradually replaced by smaller regional vessels belonging to the urban grassroots economy (which reinforces the STUR proposition), since there are considerable numbers of individuals with the skills to navigate and reach distant communities and villages.

Seasonal or pendular displacements of the river circulation from also end up reconfiguring the intra-urban space as detailed in Bartoli (2017). If the extraction of natural resources linked to urban demand or foreign markets increases, the demand for people willing to sail, practice extractivism or plant various agricultural crops also grows. This intensifies the need for mediation between territory-city-market dynamized by river circulation. The former cycles in Parintins of the extraction of rosewood oil (sap for perfumes), the cultivation of jute and malva (fibers) or uninterrupted logging or fishing are good examples. Such knowledge (know how to navigate, transit and explore the territory in a zonal / aerial sense), has been appropriated to directly or indirectly serve the commercial sectors of the city.

The structure of reticular relationships of Parintins from its Territorial Systems is conditioned by the location of the city: a relativized geographical space that is shaped by techniques, economic

(3) https://www.nytimes.com/2017/09/16/health/brasil-junk-food.html?smid=fb-share. Visited on 10/21/2017. 
and social structures and systems of relationships. It is a procedural dynamic that takes into account diverse networks and flows from a centralization process (DAMIANI, 2006).

Located in the extreme east of the state of Amazonas, the municipality is on the border with the State of Pará, bordering the municipality of Juruti (PA) and the other Amazonian municipalities of: Nhamundá, Barreirinha, Urucará and Urucurituba. It has a territorial extension of 5,952,369 $\mathrm{km}^{2}$ and in 2010 it had a population of 102,033 inhabitants (IBGE, 2010). The municipal seat is located on the right bank of the Amazon River, with unrestricted navigation throughout the year (even in years of severe drought), which places the city in a strategic point between the two regional metropolises, Manaus (AM) and Belém (PA).

The urban site is formed by a fluvial-lacustrine archipelago, accessible only by river, the connections to communities and small municipalities (north and south of the municipal seat) are most affected during the dry season, changing navigation routes by making them longer. The connections with the urban network are primarily fluvial, which gives greater weight to the role of vessels, and the typologies of the territorial systems to which they are linked.

Thus, due to its position, Parintins has become a distribution center for industrialized products originating from both Manaus and the urban network of Pará (Figure 1). Medium-sized cities such as Parintins have commercial specializations that do not exist in their smaller neighbors, such as the case of building materials, where four large groups are responsible for the distribution to the surrounding municipalities and communities in their area of influence. These groups also control the distribution of other commodities like gas, estivas and industrialized foods, because they own ferries that bring goods from the capital of Amazonas. They also contribute towards these groups' domination and concentration of the local markets, especially in recent years.

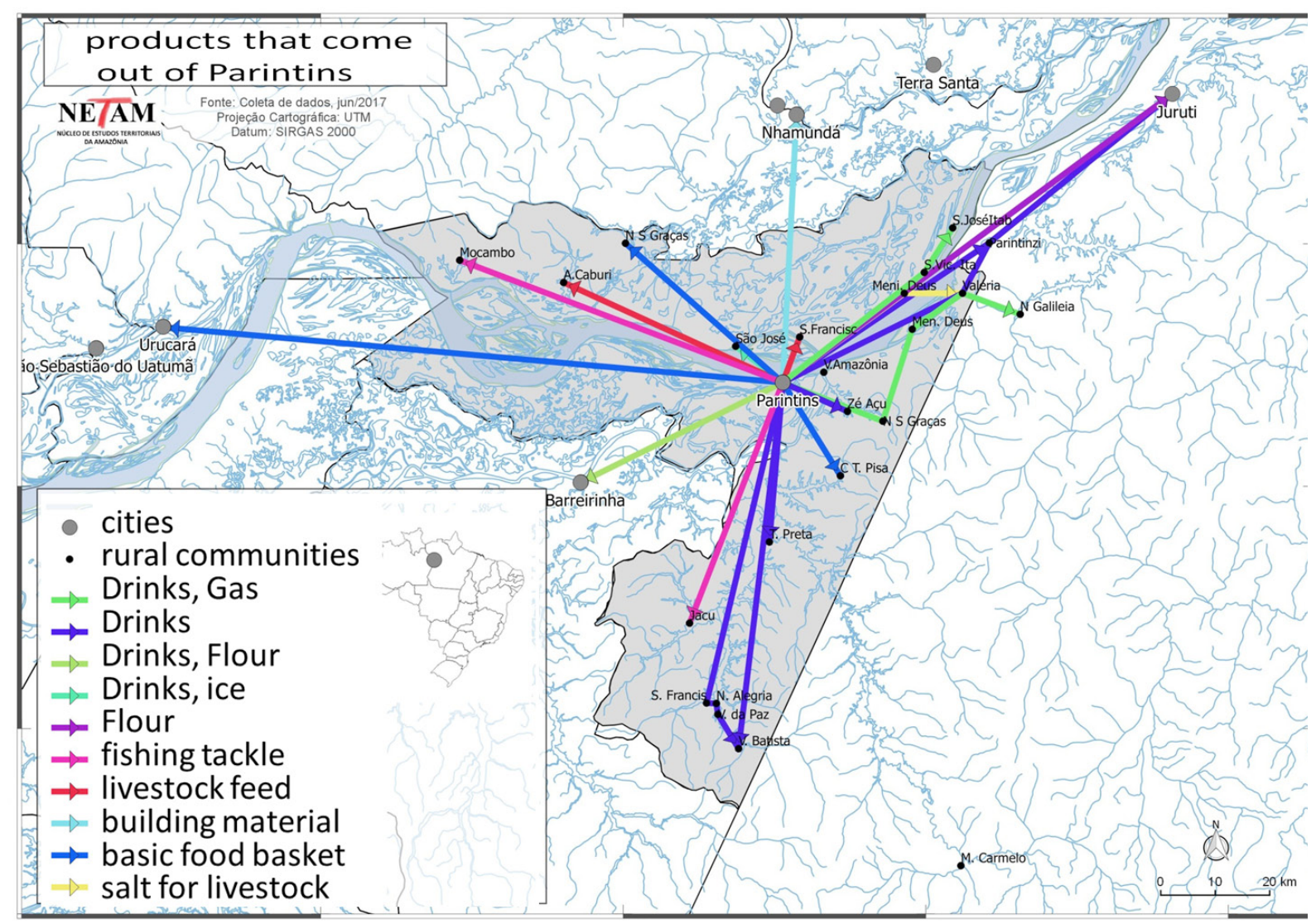

Figure 1 - Products transported from Parintins to the interior by medium-sized vessels belonging to the STUR. Source: NETAM (2017).

In the surrounding local towns, there are only more "generalist" shops that sell everything, food, appliances and even construction materials, purchased through Parintins, but transported 
by the huge number of wooden boats belonging to low-income residents of these towns, which are the main articulators of the STUR. Some communities that are closer to and easily connected to the river (including during the ebb) also have small establishments of this type, functioning as secondary nodes of distribution to smaller and more distant communities.

The distribution of ice produced in the city and the inputs for livestock from Manaus and Santarém (PA) are necessary for other flows such as the transportation of fish to fish warehouses, and the production of livestock for slaughter in the city's municipal slaughterhouse.

Therefore, the thesis of extensive urbanization can only be understood if we dwell on the analysis of the directions, intensities and modalities of the flows that depart from the city (centrifugal force), using medium-sized vessels, complementing flows to the city (centripetal force), forming part of the STUR's dynamics.

With the consolidation of the urban economy and the formation of large low-income neighborhoods, new networks are formed in variable topologies that determine the position of their nodes and their conditions of access to the various connections. They depart both from low-income riverbanks in the pursuit of income complementation, and from areas of old and new urban centralities associated with commercial capital.

Another set of theoretical-conceptual contributions subsidizes the understanding of these reticular dynamics. Among the approaches to cities in the Amazon, we must weave considerations related to the dialectic between economic specializations, regarding the functions that cities fulfill in the territorial division of labor, and the diversifications, with respect to the numerous productive manifestations such as those of the grassroots economy ${ }^{4}$ (CORAGGIO - 1991), always alert to the territorial identity of each municipality provided by the tradition of exploitation of certain regional resources.

For Santos (2004), flows are movements and circulation, and thus they explain the phenomena of distribution and consumption, while the fixed assets are the labor instruments and productive forces themselves, in general, including the mass of men. Economic space is a set of points and flows, while geographical space is the banal space, both of which are indistinguishable. The fixed assets cause flows based on their technical data, which are generally locational but also depend on the political data. The masses created by the fixed assets demand the capacity of mobility in space, being executed by the economic, political or social power. This mobility is higher or lower according to the communities, the institutions established in each social group and the action of man (Ibid., P. 84).

This is a very rich reflection to problematize the existence of territorial systems that are based on different ways of circulating along rivers, adapting techniques and using regional resources, linking and interpenetrating the urban with the diverse surroundings: the capacity to mobilize efforts to obtain results, activate points from the main node (city), weaving strategies-networks connecting the urban to the interiors ${ }^{5}$ through the rivers, differing according to the power of action of each network of subjects or organized collective.

Amazonian cities have differentiated urban profiles, with other roles in the network, incorporating not only traditional functions (banks, hospitals, services, commerce, transportation), but also consolidating from other dynamics: extractivism, fishing, hunting, small-scale farming, illegal prospecting, traffic in narcotics, etc. In addition to this dynamic, the particularities of inland navigation and the seasonality of the water regime, added to cultural and natural dimensions and temporalities that cannot be neglected, characterize the differentials of these networks to others in Brazil.

(4) Coraggio (1991, p.335) defines the grassroots economy in a first approximation, as the set of resources, practices and economic relationships proper to the grassroots economic agents of a society. "Those agents who make up reproduction units [which] depend on their own work fund (the joint capacities of work of its members) ... " (Idem, 336)

(5) The term "interior" is the most one commonly used by local people, with a generalist meaning that encompasses a multiplicity of places, villages, farms, villages and existing communities. 
In this context, innovative methodology is found in Schor (2014) and Moraes (2014), who propose the use of thematic urban networks dealing with fishing and the formation of the regionalized staple diet in the cities of the Solimões river channel (AM), where fish is traded by urban artisanal fishermen or communities form relationships that go beyond municipal boundaries. Moraes'(2014) research results show that the cities analyzed in the Alto Solimões (AM) represented the last nodes in the network established by the regionalized staple diet, on the other hand they are the first in the international catfish market network. Moraes also indicates that there is a seasonal variation in the items and prices of the regional staple diet, influenced by the flood and ebb of the river (MORAES, 2014). For the author, the thematic urban networks ${ }^{6}$ were essential to understand processes of over, super and juxtaposition of these networks, ${ }^{7}$ which involves the participation of a center in several networks with different functions, articulating several scales.

The study of thematic networks requires a method classified as the conceptual fragmentation of the object (MORAES, 2012), which uses concepts and / or definitions that constitute parts of the object to be explored in a particular and illustrative way when analyzed in particular. It mainly aims to apprehend the important specificities in the understanding of the process, which the analysis of the whole could omit. When analyzing the trade in catfish, Moraes (2012, p. 57) uses elements that can be classified as: the referential network (trade in catfish), fixed references (afloat and refrigeration) and reference flows (the paths that the merchandise travels). For the author, the description of the fixed references covers the way in which the structure of the network in its constituent points is revealed, whose spatial arrangement of the objects is constant; the greater dynamic is really due to the flows.

In such networks, fixed assets and flows can only be established if there is support for their operation, and are called adjacent flows, consisting of products considered as basic inputs for the particular activity under analysis: 1) food supply flows; 2) fuel supply flows to cities; 3 ) communication flows via telephone; 4) financial flows (Ibid., P.58).

These theoretical contributions are useful in the structuring of the STUR model, broadening the analysis of thematic networks, proposing that such flows: a) are responsible for supplying grassroots markets and stores with regional products; b) supply items for the reproduction of the commercial capital of medium-sized urban enterprises (fishing depots, slaughterhouses, loggers, slaughterhouses, etc. - figure 2); c) work as "returns to territories", because local networks of subjects of the grassroots economy begin to rebuild projects through the consolidation of organized collectives or market incentives of urban demands, without losing the "umbilical" ties that these populations have with their original communities (BARTOLI, 2017); d) model intra-urban space by altering the morphology of the city, as will be seen below, based on the analysis of the set of fixed assets in large low-income neighborhoods originating from irregular occupations.

(6) This type of methodology is extremely important because the IBGE's approach to the analysis of urban hierarchy does not encompass all the multiplicity of relationships existing in these cities, thus, it is necessary to investigate other sets of variables to better understand the Amazonian urban network, proposing typologies of cities and overcoming analytical resources that are based on the rural-urban dichotomy.

(7) Another analysis of the thematic network, regarding the management of pirarucu in the city of Fonte Boa (Solimões river channel - AM), Carvalho (2010) 


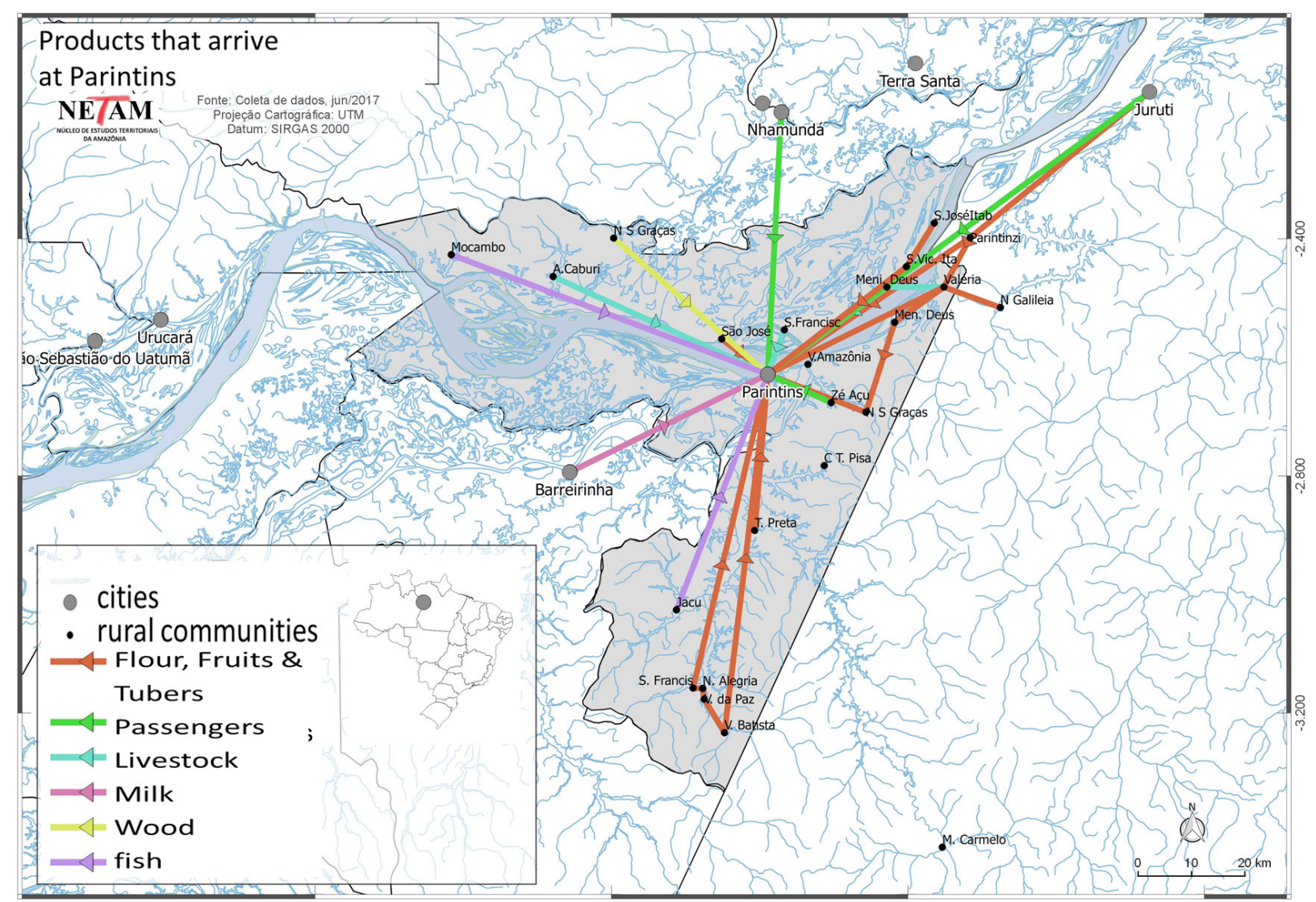

Figure 2 - Existing thematic networks in Parintins - Source: NETAM (Nucleus of Territorial Studies of the Amazon)

The existing thematic networks in Parintins (Figure 2), seen as reference flows, help in the understanding of the sub-urban urban network and are essential for structuring the operational logic of the STUR. The flows of flour, fruit and tubers come from small-scale family farming, supplying stalls, markets and small grocery stores in low-income neighborhoods. The data on wood flows are difficult to obtain, as they mostly occur illegally, but are easily detectable on riverbanks in low-income neighborhoods. Fishing is strictly conditioned by physical aspects, with the lakes to the west of the city having more fish, whilst dark and more acidic rivers are less attractive for commercial fishing, and legal aspects (areas protected by Conservation Units or Fisheries Agreements ). Flows of cattle transport also require detailed studies, since $83 \%$ of municipal livestock production comes from small producers (SEMPA, 2017), who also perform secondary functions in the city, owning small butcher shops and barbecue stands, signaling characteristics of the STUR: their duality, because in addition to connecting city-interiors, these subjects have activities in the city and interiors to supplement their income.

\section{THE STUR METHODOLOGICAL PROPOSAL: "NAVIGATORS" TERRITORIALITIES AND THE GRASSROOTS ECONOMY}

This continuous and accelerated reproduction of urban-regional spaces with constant migratory flows, exodus, consolidation and growth of cities, refers to concepts (reinterpreted to other contexts) such as those of territory and territoriality (DEMATTEIS, 2005; SACK, 2013; RAFFESTIN, 2009; RAFFESTIN; BRESSO, 1979; SAQUET, 2011). A space becomes a territory through processes of appropriation, influence, control and domination, therefore, territories must be understood as mul- 
tiple in their relationships, manifestations and organizations. The territory is not only linked to its political-administrative sphere. Rather, it involves symbolic, cultural, and economic relationships, as well as how people make use of their space and give meaning to a place (HAESBAERT, 2012).

The diversified academic production considered so far, provides a basis for observations in our research that have as an interpretive key the ability of the networks of subjects belonging to the grassroots economy to fulfill an important role of interconnection with interiors. The riparian dynamic is amplified by being relational. It is both a point of connection as a flow for the creation of networks and the materialization of the project of each group based on the "facilities" and possibilities that the city offers.

The STUR demonstrates the spatial behavior of the circuits of the grassroots economy inserted in a specific context, with spatial practices whose analytical cut prioritizes areas of influence of the city of Parintins. In spite of privileging sub-regional and intra-urban dynamics, the consideration of trans-scale dynamics is essential, requiring future studies to better detail these existing complex relationships with the regional urban network (with the strong influence of the Manaus metropolis in dispute with the urban network of Pará), and national and global scales. These connections end up being evidenced by the type of industrialized goods that are distributed by Parintins, coming from the capital of Amazonas and other regions from Santarém (PA) and Belém (PA). The existence of fixed assets and adjacent flows is also necessary in the realization of the STUR's centrifugal and centripetal forces.

Briefly, the mediating role that the STUR covers appears in five strands: i) zonal and topological: connecting the city through thematic networks to the various points of the sub-regional surroundings by inland river transport; ii) the production and configuration of intra-urban spatial fragments constituting useful fixed assets for navigation, for example; iii) dual and complementary economic: driven mainly by the grassroots economy but in constant interaction with the spheres of commercial capital appreciation dominant in the city (in some cases, scalar leaps occur in various relationships that go beyond the subregion); iv) organizational and institutional: other types of coalition of subjects gain relevance (cooperatives, associations, fishermen's colonies, etc.), mediating actions that unfold in practices on the territory; v) symbolic-cultural: traces of rural, riparian and indigenous culture or grassroots knowledge are absorbed and resignified by insertion the urban process. Due to the nature of the data presented, we will detail the first strand. The others are presented in Bartoli (2017).

i) River navigation and sub-regional dynamics

At the subregional scale, navigation flows dynamize areas of varying coverage. Countless canoes of varying sizes on the city's riverbanks, not registered with the Port authorities, are very useful for the configuration of the STUR, as they travel short and medium distances through shallow water channels, reaching areas and resources not accessible to other vessels. Rabetas and bajarinhas are agile in narrow channels and extract resources that also supply the dominant commercial system with fish, wood and even gold from clandestine mines and marijuana grown in the municipality of Maués (AM). Used to circumvent territories with fishing agreements (lakes protected by communities with support from IBAMA and other institutions) or Conservation Units, they are rarely caught by the negligible enforcement or by the local communities monitoring protected lakes. These extremely complex circuits of circulation also reach distant areas, internalizing tensions and conflicts rarely reported in the cities, and supplying urban commercial sectors in various ways. They thus help to form territorial systems strengthened by illegality, denoting power to the urban elites who are enriched by such activities.

Meanwhile, the batelão (barge), which is a medium-sized wooden hull that varies between 12 and 20 meters, has several functions, appearing as one of the clearest materializations between the STUR and the Territorial System structured by large commercial companies. It is the most regionally 
wide-spread model of boat and adapted to varied activities like the transport of cattle, fish, wood and even act as gas stations. They also serve as housing due to the city's huge housing deficit. They can be commanded by experienced captains, connoisseurs of the intricate and complex paths that change according to the seasonality of water. However, they also supply commercial sectors such as fishing companies and wood extraction or transport a few heads of cattle.

Such vessels used in the STUR are flexible connectors of the intermediation between "two worlds" (cities - interiors) which, in our view, interpenetrate and overlap in various instances, appearing as a technical mediation of this logic: old boats, bajaras, baljeiros and canoes, which are becoming more and more adapted to the characteristics of the grassroots economy, influenced by the reproduction of urban commercial capital or of higher circuits linked to large companies (the distribution and consumption of products, as we have seen). They serve the inhabitants of the Amazon in the seasonal oscillation of the waters in the increasingly intense "to and fro" between city-rivers-interiors. These wooden vessels still transport people from communities that do not have transportation via aluminum boats, which have recently become notable in municipal centers.

\section{ii) Intra-urban space}

On the intra-urban scale, riversides in low-income neighborhoods are interpreted as nodes for the construction of spatial practices, having important points of centrality (markets, floating, jetties, groups of buildings on stilts, small ports, etc.). These spaces contribute to the formation of urban-riparian territorialities, conditioning the way in which subjects circulate and delimit those multireticular nodes composed by set of fixed assets.

These are added to the economic activities that make up the STUR, the small informal stores in low-income neighborhoods, and the various interactions and conditionings linked to the reproduction of commercial capital. This capital has been transforming the forms of the city for its own benefit (described in the typologies of riversides - BARTOLI, 2017, 196), increasingly reducing riverfront living spaces with the privatization of the banks that are subject to the exchange domain , whose logic of property overlaps with the free use of rivers that diverse populations have always had, but without anuling them. Long stretches on the riverbanks in Parintins have been almost entirely submitted to this logic of appropriation of space, segregating and prohibiting the mooring of small boats, imposing an external rationality (geometric forms to the use of altered riverbanks in the evolution of the urban plan), affecting other forms of appropriation. To the detriment of small and medium-sized wooden vessels, there are large ferries and iron boats, floating gas stations and "jet" boats. ${ }^{8}$

These spatial refutations appear as "clues" interpreted as manifestations of disputes for access to points in the city that serve as supports to connect interiors or link the city to the regional urban network. Such fragments on riverbanks indicate that the urban process does not end in such forms. Rather, it unfolds in the way the vessels form the mediator-connector axis of the STUR. The construction of these fragments demonstrates the different capacity of subject networks to produce such spatial configurations, emphasizing the exercise of power: privileged points for exclusive use of the dominant territorial system.

iii) Dominant commercial territorial system

The STUR is vital for the activities carried out in the dominant commercial territorial system, being driven and exploited by it. It can therefore be said that there is an Urban-Fluvial Territorial

(8) Popular name given to aluminum speedboats that travel in up to a quarter of the time spent by slower wooden vessels. 
System (STUF), tied to this commercial capital, ${ }^{9}$ which increasingly overlaps and absorbs riparian dynamics. This is evident by the apprehension of the landscape and mapping of urban land uses associated with the fishermen's reports (participatory cartography exercises - Bartoli, 2017). We use the term fluvial considering that, for the subjects that drive this system, the rivers are used primarily for the circulation of goods. There is no intention of maintaining daily practices, which have in the river a symbolic, cultural / identity (riparian), ludic or subsistence aspect, it is a system linked to activities linked to diverse scalar relationships, mainly with the Manaus metropolis.

Groups of local big businesspeople constitute the STUF, with the city as a node for the extraction of natural resources and base of actions where: i) There is spatial repercussion, since they have a greater power to organize spaces due to their ownership of lots and land, materialized mainly in the ports, which gives a greater extraction of income; ii) Encourage economic circuits that generate a greater environmental impact in large areas from actions such as extraction of wood, sand, gravel and livestock, buffaloes, commercial fishing, etc.; (iii) use of vessels: large cargo rafts, fuel rafts, tugs, gas tanker boats, large iron boats, motorboats and private yachts. ${ }^{10}$

Although also affected by natural cycles (mainly river seasonality), the STUF has a higher recursive margin to minimize the effects. Notably, possession of the city's waterfront land that is navigable throughout the year and the nature of the boats and places accessed. They do not need to transit through furos, paranás (minor branches) or lakes to search for resources (they delegate this to STUR!). A striking example occurs in the comparison of the STUF ports located on the year-round waterfront of the city, and the floating-marina in low-income neighborhoods, located in peripheral lakes of the city, subject to the droughts that prevent access to such districts via navigation. This unequal production of space affects the mobility of the people who suffer by leaving their boats away from their homes in the drought, needing to pay for lookouts.

Increasingly, STUR and STUF complement and interpenetrate each other. This is due to the acceleration of the processes of urbanization, the intensification of the demand for natural resources in the city, and the propagation of the urban way of life and consumption.

In summary, Figure 3 shows the interaction and composition between the systems. The dotted circumferences (permeabilities and interpenetrations) represent the comprehensiveness of the systems and interactions between STUR and STUF, reaching riparian territorial systems with little interaction with the city.

(9) There is a varied pulverization of the investments of so-called mercantile capital, which in constant metamorphosis adapts to various circumstances and scenarios. In the case of Parintins, these spheres also take advantage of the boom generated by the success of the Festival Folclórico, being inserted in hotel activities, supermarket chains, tourism agencies, rental companies of sound and lighting equipment, etc.

(10) We will leave aside the freighters used to transport products produced by the industrial pole of Manaus and the transatlantic tourists that anchor in Parintins, as they would require an expansion of the systems linked to other fractions of capital but would be the subject of fruitful studies in future research. 


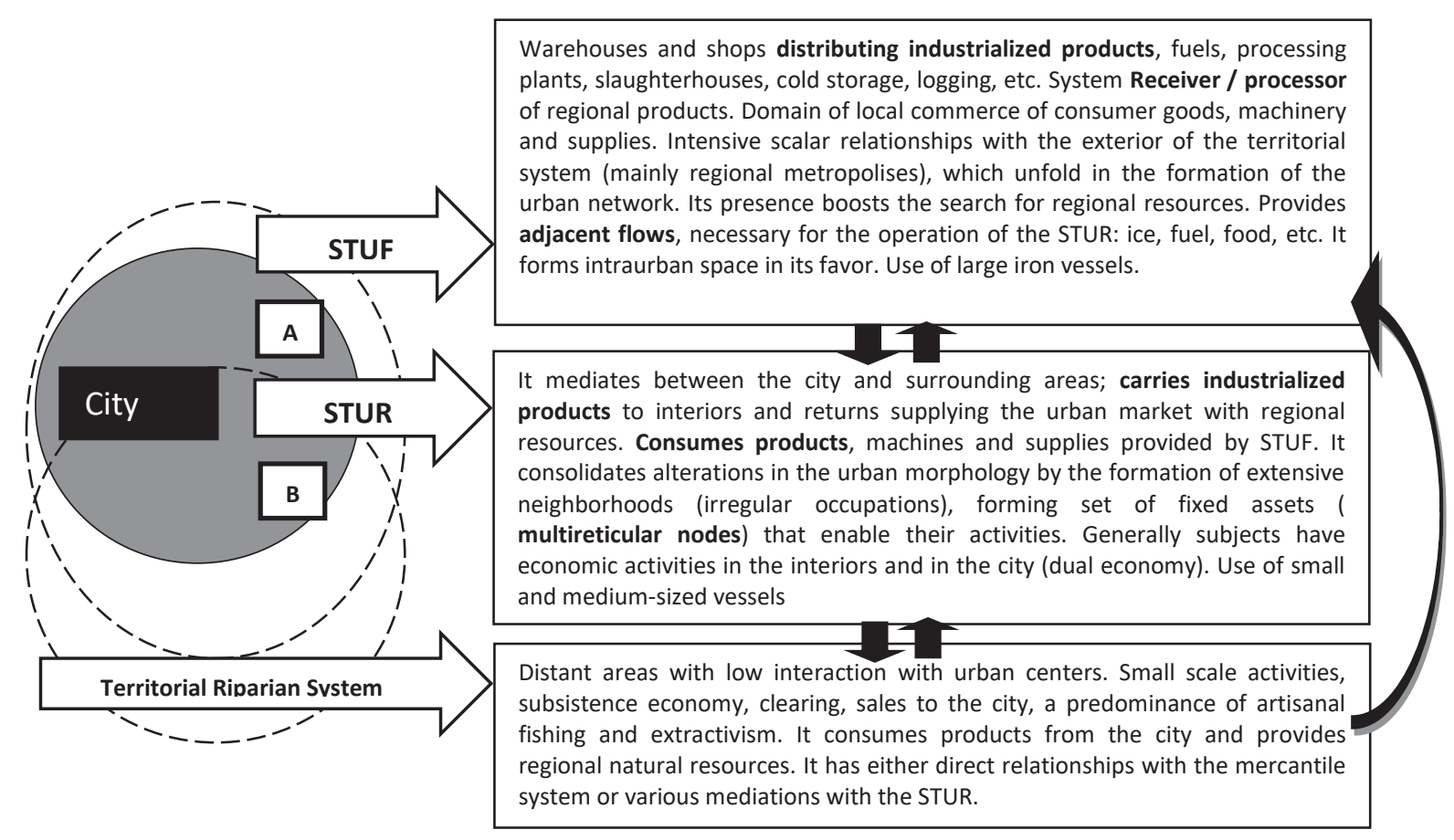

A - Tensions and conflicts: production of urban space (emphasis on river banks).

B - Hybridization: elaboration of creative solutions and technical adaptations in working instruments, housing, types of vessels and other perceptible spatial forms in low-income neighborhoods.

Figure 3 - Connections between territorial systems mediated by the city. Organized by the author.

\section{FINAL CONSIDERATIONS}

The lack of internal economic dynamism of cities with intense riparian dynamics such as Parintins requires that other methodological proposals be discussed, whose analysis thus aims to contribute: in cities dynamized by flows through river transport (regional and subregional), the local networks of subjects distribute industrialized products to the interior communities using small and medium-sized vessels, whose owners are also small traders, farmers, cattle ranchers or fishermen, who transit between the city and interiors. These networks of subjects that make up the STUR require innovative methodologies to understand their dynamics: trans-scalar, reticular and nodal.

Territorialities are constructed from the spatial practices, where restricted accesses and unequal rights of production and territorial planning can be delimited (mainly in the intra-urban space as a multireticular node), conferring upon it the classic definition linked to the exercise of power. The Territorial Urban-Fluvial System begins to order the territorial division of labor in its favor, affecting the other systems by imposing a more functional logic, dictating prices and controlling the urban market of absorption of products and goods from forests and rivers. On the other hand, it does not negate the spatial practices (with strong cultural characteristics) and creative territorialities of other systems.

The centrifugal force of the STUR is related to the search of the dual complement that has been repeated throughout the text: the dominant commercial economy influencing the grassroots (benefitting from its knowledge) and composing a significant part of the urban economy. The city's structure provides conditions for spatial practices, providing a basis for action so subjects can to reach increasingly distant locations, thus distributing industrialized products, dialoguing with the thesis of extensive urbanization. The data show the substantial increase in the spatial circumscription that this grassroots economy is capable of achieving, which also allows the exploitation of regional products for the city. 
The centripetal force in STUR consists of the continuous movement of populations that: a) Migrate in the search of the benefits and improvements that the city offers, as in access to services, development institutions, banks, markets and many other urban "facilities", inducers of new contexts of insertion of subjects in the city. b) Needs to "absorb" recursive complements of the interiors to complement their income: wood for low-income housing, boats or small furniture industries; fish for food or processing; straw; piaçava; hunting meat or chelonians, small livestock production, etc.

The complex interaction between the two territorial systems (STUR and STUF) functions as the structuring of the direct sphere of urban influence of Parintins. Both in the nodal-zonal aspect, as they connect fragments of the intra-urban space through their water flows to surrounding territories, and in the relational aspect. They allow the interpenetration of activities to complement the urban economy, influencing (or being influenced by, as in the case of STUR) the use and reordering of territories. These types of studies can be good alternatives for the understanding of the dynamics in the production of territories that surround cities in the Amazon.

\section{BIBLIOGRAPHIC REFERENCE}

ARAUJO, Felipe Nascimento. As diferentes formas de relação patrão/freguês. 2016. 174 f., il. Dissertação (Mestrado em Antropologia Social)—Universidade de Brasília, Brasília, 2016.

BARTOLI, E. Ações Indígenas Sateré-Mawé na Cidade de Parintins (AM) e a Formação de Sistemas Locais Territoriais Urbano-Ribeirinhos. In: Simpósio Nacional de geografia Urbana (SIMPURB), CD-room. Fortaleza: UFCE, 2015.

BARTOLI, E. O Retorno ao Território a partir da cidade. Presidente Prudente: PPGG / UNESP, (Tese de Doutorado), 2017.

BECKER, B. K. Amazônia. São Paulo: Ed. Ática. Série Princípios, 1990

BECKER, B. K. Amazônia. Rio de Janeiro: Garamond, 2004.

BECKER, B. K. A Urbe Amazônida. Rio de Janeiro: Garamond, 2013.

BROWDER J.O. GODFREY, B.J. Cidades na Floresta. Manaus: EDUA, 2006.

CORAGGIO, J. L. Ciudades sin rumbo. Quito: Ciudad - SIAP, 1991.

DAMIANI, A. L. Cidades Médias e Pequenas no Processo de Globalização. In: América Latina. CLACSO: São Paulo, 2006.

DEMATTEIS, G. Il sistemi territoriali in um'ottica evoluzionista. in: DEMATTEIS G. GOVERNA, F. (orgs.). Territorialità, sviluppo locale, sostenibilità. Milano: Angeli, 2005.

DEMATTEIS, G. Sistema Local Territorial (SLoT): um instrumento para representar, ler e transformar o teritório. In: ALVES, A. CORRIJO, B. CANDIOTTO, L. (orgs.). Desenvolvimento Territorial e Agroecologia. São Paulo: Expressão Popular, 2008.

GENTIL, Janete. A noção do Urbano em Áreas de Fronteira: uma revisão teórica. in: Seminário sobre Amazônia: a fronteira agrícola 20 anos depois. Belém: Museu Paraense Emílio Goeldi, 1988.

HAESBAERT, R. O Mito da Desterritorialização. Rio de Janeiro: Bertrand Brasil, 2012.

IBGE. Censo Demográfico 2010. Disponível em <www.ibge.gov.br>. 2010. Acesso em 23/10/2014.

MONTE-MÓR, R.L. A Urbanização Extensiva e Lógica de Povoamento. SANTOS, Milton et. al. (orgs.) Território, globalização e fragmentação. São Paulo: Hucitec/Anpur, 1994 (pp. 169-181)

MONTE-MÓR, R.L. A relação urbano-rural no Brasil contemporâneo. Trabalho apresentado no "I seminário Internacional Sobre Desenvolvimento Regional”. Santa Cruz do Sul - RS, UNISC, Out. 2004.

MONTE-MÓR, R.L. As Redes Para Além dos Rios. in: Nova Economia - Belo Horizonte: 19 (1), 11-39, jan-abr. 2009.

MORAES, A. O. "peixe, farinha e frango congelado: rede urbana e alimentação na calha do rio Solimões." In: Anais do XV Encontro Nacional de Geógrafos (ENG). São Paulo: 2008. 
MORAES, André de Oliveira. Peixes, redes e cidades. Dissertação (Mestrado em Ciências do Ambiente e Sustentabilidade na Amazônia) - Universidade Federal do Amazonas, - Manaus: UFAM, 2012.

MORAES, A. Embalando Mercados em Redes Urbanas: alimentação e pesca articulando cidades na Amazônia brasileira. in: SCHOR, T. (org.). Dinâmica Urbana na Amazônia - vol. 1. Manaus: Valer, 2014.

MORAES, A. O. SCHOR, T. ALVES-GOMES, J. A. O Mercado de Bagres e a Configuração da Rede Urbana no Alto e Médio Solimões, Amazonas, Brasil. Caderno Prudentino de Geografia. V.1, n.32, p.93-110. 2010. OLIVEIRA, J. A. Cidades na Selva. Manaus: Valer, 2000.

OLIVEIRA, José Aldemir de; SCHOR, Tatiana. Urbanização na Amazônia. GEEA-Grupo de Estudos Estratégicos Amazônicos - Caderno Debates, vol. III, Manaus: Editora do INPA, 2010. 147-189.

RAFFESTIN, C. Por Uma Geografia do Poder. São Paulo: Ática, 1993.

RAFFESTIN, C. A produção das estruturas espaciais e sua representação. In: SAQUET, M. e SPOSITO. Territórios e territorialidades. Teorias, processos e conflitos. São Pailo: Expressão popular, 2009.

RAFFESTIN, C. BRESSO, M. Travail, Space, Pouvoir. Lausanne: L'Age d' Homme, 1979.

SACK, R. O significado de territorialidade. in: Leila Cristina Dias e Maristela Ferrari (orgs.). Territorialidades Humanas e Redes Sociais. Florianópolis: Insular, 2013.

SANTOS, M. A Natureza do Espaço. São Paulo: EDUSP, 2004.

SANTOS, M. SILVEIRA, M. L. Brasil. Rio de Janeiro: Record, 2003.

SAQUET, Marcos Aurélio. Abordagens e Concepções de Território. São Paulo: Expressão Popular, 2007. SAQUET, Marcos Aurélio. Por uma Geografia das Territorialidades e das Temporalidades. São Paulo: Outras Expressões, 2011.

SEMPA. Plano de Ação para o Setor Primário de Parintins, Prefeitura Municipal de Parintins - PMPSecretaria Municipal de Pecuária, Agricultura e Abastecimento - Sempa, 2017.

SCHOR, Tatiana; COSTA, Danielle, P; OLIVEIRA, J. A. Cidades, rede urbana e desenvolvimento na Amazônia dos Grandes Rios. In: TRINDADE Jr., Saint-Clair Cordeiro; CARVALHO, Guilherme; MOURA, Aldebaran; GOMES NETO, João. (Org.). Pequenas e médias cidades na Amazônia. Manaus: FASE/ UFPA, 2009, v. , p. 35-58.

SCHOR, T. (org.). Dinâmica Urbana na Amazônia Brasileira. Manaus: Valer, 2014.

SILVA, M. A. MALHEIRO, B. C. P. A face Ribeirinha da Orla Fluvial de Belém. In: TRINDADE JR., Saint Clair Cordeiro da; SILVA, Marcos Alexandre Pimentel da (orgs.). Belém. Belém: EDUFPA, 2005.

TRINDADE JR. S. C. Cidades na Floresta: os "grandes objetos" como expressões do meio técnico-científico informacional no espaço amazônico. Revista IEB, n50 set./mar. 2010.

TRINDADE JR. S. C. SILVA, M. A. P. AMARAL, M. D. B. Das "Janelas" às "Portas" para os Rios: compreendendo as cidades ribeirinhas na Amazônia. in: TRINDADE JR. S. C. TAVARES, M. G. Cidades Ribeirinhas na Amazônia. Mudanças e Permanências. Belém: EDUFPA. 2008.

VICENTINI, Y. Cidade e História na Amazônia. Curitiba: UFPR, 2004. 